\title{
Bone Magnesium Pools in Uremia
}

\author{
Allen C. Alfrey and Nancy L. Miller \\ From the University of Colorado Medical Center and Denver Veterans \\ Administration Hospital, Denver, Colorado 80220
}

A B S T R A C T Bone magnesium pools were studied in vitro in bone specimens obtained from control subjects, from patients with chronic renal failure before and after renal transplantation, and in a patient with chronic hypomagnesemia. $30 \%$ of bone magnesium is in a surface limited pool present either within the hydration shell or else on the crystal surface. The larger fraction of bone magnesium was shown not to be associated with bone matrix but rather to be an integral part of the bone crystal. With incineration this pool was mobilized at the same temperature that sudden enlargement of bone crystal size occurred. It is suggested that heating causes surface calcium to displace magnesium from the apatite crystal. Both magnesium pools are increased in patients with chronic renal failure.

The major factor determining magnesium concentration in bone would appear to be the serum magnesium level. Following renal transplantation, in association with the fall in serum magnesium, surface magnesium was within the normal range; whereas, residual magnesium was not different from the other uremic bones. Both magnesium pools were significantly reduced in a patient with chronic hypomagnesemia. The in vitro studies would suggest that surface magnesium should rapidly reflect changes in serum magnesium levels, whereas, the deeper magnesium pool is probably deposited at time of bone formation with mobilization being dependent upon the resorptive processes. Since magnesium can influence crystal size and stability it seems possible that excess bone magnesium may play a role in renal osteodystrophy.

\section{INTRODUCTION}

$60 \%$ of total bdoy magnesium resides in the skeleton; however, few studies have been carried out to characterize bone magnesium pools (1). Based on the studies of Blaxter (2) and Neuman and Mulryan (3) it has been felt that magnesium is largely a surface limited ion (hydration shell and/or crystal surface) and is incapable of

Received for publication 9 April 1973 and in revised form 16 July 1973. penetrating into the lattice structure (3). This would imply that all bone magnesium would exist in an exchangeable magnesium pool. Blaxter was able to show that virtually the whole of skeletal magnesium participated in magnesium depletion in calves, whereas a much smaller percent was available during magnesium depletion in adult animals (2). Similarly studies by Breibart, Sup Lee, McCoord, and Forbes have shown that only $30-40 \%$ of bone magnesium is exchangeable in young rats and this decreases to $4-6 \%$ in older animals (4). Although the lack of exchangeability in older animals has been related to poor circulation in old established bone (2) it seems equally possible that the entire bone magnesium pool may not be exchangeable. Not only is bone magnesium mobilizable during magnesium depletion but with magnesium loading bone magnesium increases $(5,6)$. Again it is unknown where magnesium deposition occurs in these bones.

A recent study by Contiguglia, Alfrey, Miller, and Butkus has shown that bone magnesium is usually increased in patients with chronic renal failure (7). This finding has subsequently been confirmed by two other groups $(8,9)$. The present study was thus undertaken to characterize bone magnesium in control bone, to determine how bone magnesium pools are affected during magnesium excess and how these pools are changed by reinstitution of renal function and reduction of serum magnesium levels.

\section{METHODS}

Bone was obtained from five control subjects, eight dialyzed uremic patients, eight nondialyzed uremic patients, four post-transplant patients who died of nonrenal causes and had good renal function until the time of death, and one patient with chronic hypomagnesemia. The controls were nonhospitalized patients (obtained through the Denver Coroner's Office) who experienced sudden death, usually auto accident victims. The eight dialyzed uremic patients had been maintained with chronic hemodialysis using a $1.2 \mathrm{meq} /$ liter $\mathrm{Mg}$ concentration in the dialysate for $4 \mathrm{mo}$ to $4 \mathrm{yr}$ prior to death. All but one patient had documented chronic uremia for a minimum of $2 \mathrm{yr}$.

Elution and incineration studies were performed in all control bones, eight dialyzed uremic patients' bones, two 
nondialyzed uremic patients' bones, four post-transplant patients' bones, and bone from a patient with chronic hypomagnesemia. Bones were obtained at autopsy from the iliac crest. Adhering tissue and periosteum were removed by scraping with a scalpel. Cortical and trabecular bone were separated and the marrow removed by washing with a jet of deionized water. After air drying at room temperature the bones were ground in a Wiley mill and passed through a 20 mesh sieve. Partial defatting was accomplished by rinsing four times with petroleum ether (hp 30 $\left.60^{\circ} \mathrm{C}\right)$. The bone was then reground and passed through a 60 mesh sieve. A portion of this preparation was reserved for fresh bone powder studies. The remainder of the sample was dried at $130^{\circ} \mathrm{C}$ overnight and then ashed at $550^{\circ} \mathrm{C}$ for $16 \mathrm{~h}$ in a Thermolyne Type 1900 furnace equipped with a Furnatrol temperature controller. Fresh, dry, and ashed weights were obtained to determine the percent ash of the bone specimens. All values are expressed on an ashed weight basis. This value is calculated from the percent ash where necessary.

Radiomagnesium studies. Four $10 \mathrm{mg}$ portions of fresh hone powder were equilibrated with $0.9 \mathrm{ml}$ barbital buffer containing $0.001 \mathrm{M} \mathrm{MgCl}$. After $16 \mathrm{~h} 5 \mu \mathrm{Ci}{ }^{28} \mathrm{Mg}$ (Brookhaven National J.aboratory, Upton, N. Y.) in $0.1 \mathrm{ml}$ of the same buffer solution was added to each tuhe. The tubes were mixed by mechanical inversion for periods of $1,2,3$, and $4 \mathrm{~h}$.

At these times $0.5 \mathrm{ml}$ supernatant fluid was withdrawn for counting in a two-channel deep well scintillation counter. Appropriate corrections were made for the contribution of ${ }^{28} \mathrm{Al}$. The bone residuals were pooled, ashed, and analyzed for ${ }^{24} \mathrm{Mg}$. Additional ${ }^{28} \mathrm{Mg}$ studies were performed with sampling obtained between $5 \mathrm{~min}$ and $48 \mathrm{~h}$ in six bones to determine rapid and slow exchange.

Buffer elution. The buffer solution consisted of $0.005 \mathrm{M}$ sodium barbital in $0.15 \mathrm{M} \mathrm{NaCl}$ adjusted to $\mathrm{pH} 7.4$ (10). $3 \mathrm{ml}$ of buffer was added to $25 \mathrm{mg}$ of fresh or ashed bone and mixed mechanically by inversion for $1 \mathrm{~h}$. The sample was then centrifuged and the supernatant fluid drawn off for analysis. This procedure was repeated up to seven additional times with fresh buffer. The majority of the clutable magnesium was removed in the first three to four tubes with only small amounts of magnesium lost in subsequent elutions (Fig. 1). The total ions removed from the bone in the first four elutions is subsequently referred to as the elutable fraction. Residual magnesium was calculated as the difference between the total and elutable magnesium. There was good agreement between this calculated value and direct measurement of residual magnesium following elution. Equilibration studies were performed by mixing $20 \mathrm{mg}$ bone for $24 \mathrm{~h}$ with a single portion of $12 \mathrm{ml}$ buffer containing approximately $1.0,2.0$, or $4.0 \mathrm{meq} /$ liter Mg.

To further characterize the elutable pool additional studies using ${ }^{28} \mathrm{Mg}$ were carried out in two bones. The bones were allowed to equilibrate for $4 \mathrm{~h}$ in a buffer solution containing $1.8 \mathrm{mEq} /$ liter $\mathrm{Mg}$ and ${ }^{28} \mathrm{Mg}$. The supernatant fluid and bones were separated and counted. The bones were then eluted for four $1 \mathrm{~h}$ periods using a total of $12 \mathrm{ml}$ of non-Mg-containing buffer. At the end of the fourth period, bone and supernatant fluid were counted for ${ }^{23} \mathrm{Mg}$ and analyzed for ${ }^{24} \mathrm{Mg}$. Over $75 \%$ of the ${ }^{28} \mathrm{Mg}$ that had exchanged with the bone magnesium pool had been eluted. The specific activity in the elution fluid was

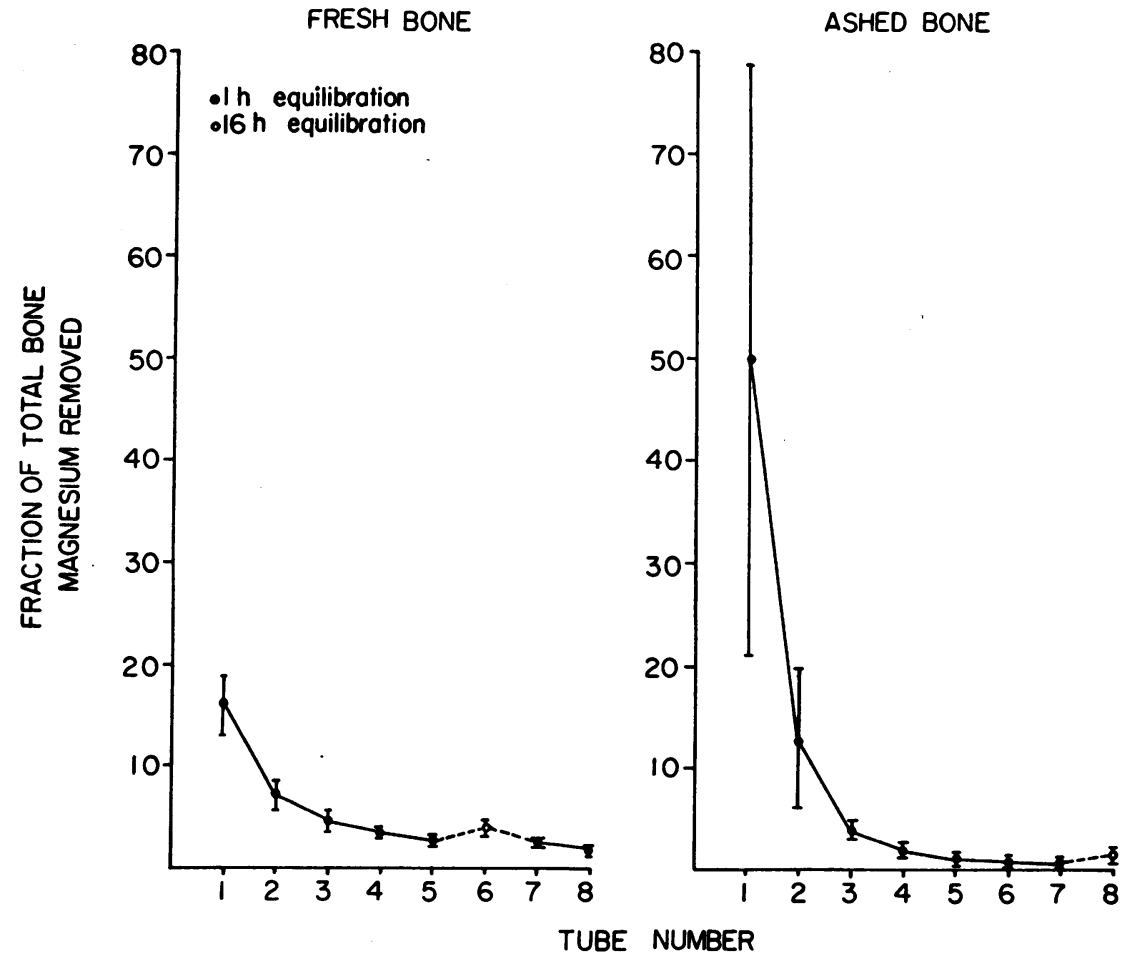

FIGURE 1 Fraction of total bone magnesium removed in each elution period. Each point represents the mean $\pm 1 \mathrm{SD}$ of the eight bones studied. 
$80 \%$ of that found in the buffer solution at the end of the equilibration period showing that the majority of elutable $\mathrm{Mg}$ is in this exchangeable $\mathrm{Mg}$ pool.

Chemical analysis. Bone ash was dissolved in $0.5 \mathrm{ml}$ $37 \% \mathrm{HCl}$ and diluted to $5 \mathrm{ml}$ with deionized water. The solutions and eluants were diluted to an appropriate volume in lanthanum chloride $(0.5 \% \mathrm{La})$ for calcium and magnesium analysis on a Perkin-Elmer 290B Atomic Absorption Spectrophotometer (Perkin-Elmer Corp., South Pasadena, Calif.). Phosphorus was analyzed according to the method of Chen, Toribara, and Warner (11).

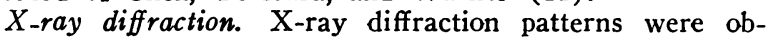
tained with a Norelco diffractometer using $\mathrm{K} \propto$ copper radiation $(35 \mathrm{keV}, 20 \mathrm{~A})$ at a scanning speed of $1^{\circ} / 2 \mathrm{~min}$.

\section{RESULTS}

Bone magnesium concentration in the five control subjects, eight dialyzed uremic patients, and eight nondialyzed uremic patients are shown in Table I. Only one uremic patient, who had renal failure for only $4 \mathrm{mo}$, had both cortical and trabecular bone magnesium levels within the normal range. Cortical and trabecular bone magnesium levels were significantly higher in both uremic groups when compared with the controls (Table I). However, there was no significant difference between bone magnesium levels in the two uremic groups (Table I).

\section{Bone magnesium pool}

Surface magnesium. The exchangeable bone magnesium pool was evaluated in the control and uremic bone using ${ }^{28} \mathrm{Mg} .{ }^{28} \mathrm{Mg}$ exchange was very rapid with maximum bone uptake occurring within the first $5 \mathrm{~min}$. Exchange was virtually complete by $4 \mathrm{~h}$ with little additional bone uptake occurring between 4 and $48 \mathrm{~h}$ (Fig. 2). This exchangeable magnesium pool represented $35 \%$ of bone magnesium in control bone as compared with $30 \%$ in uremic bone.

To further characterize the rapidly exchangeable magnesium pool elution studies were performed on the 14 bones studied with ${ }^{28} \mathrm{Mg}$. Magnesium was rapidly eluted from both control and uremic bones. The mean elutable

TABLE I

Cortical and Trabecular Bone Magnesium

\begin{tabular}{|c|c|c|c|c|c|c|}
\hline & \multicolumn{3}{|c|}{ Cortical bone magnesium } & \multicolumn{3}{|c|}{ Trabecu lar Bone Magnesium } \\
\hline & $\begin{array}{c}\text { Dialyzed } \\
\text { uremic }\end{array}$ & $\begin{array}{c}\text { Non- } \\
\text { dialyzed } \\
\text { uremic }\end{array}$ & Control & $\begin{array}{c}\text { Dialyzed } \\
\text { uremic }\end{array}$ & $\begin{array}{l}\text { Non- } \\
\text { dialyzed } \\
\text { uremic }\end{array}$ & Control \\
\hline & \multicolumn{3}{|c|}{$\mathrm{mmol} / \mathrm{kg}$ ash } & \multicolumn{3}{|c|}{$\mathrm{mmol} / \mathrm{kg}$ ash } \\
\hline Number & 8 & 8 & 5 & 8 & 6 & 5 \\
\hline Mean & 259 & 253 & 176 & 310 & 280 & 211 \\
\hline SD & 70 & 69 & 10 & 70 & 77 & 10 \\
\hline \multicolumn{7}{|l|}{$P$ values } \\
\hline \multirow{3}{*}{\multicolumn{4}{|c|}{$\begin{array}{l}\text { Dialyzed vs. nondialyzed uremic } \\
\text { Nondialyzed vs. control groups } \\
\text { Dialyzed vs. control groups }\end{array}$}} & \multicolumn{3}{|c|}{$>0.2$} \\
\hline & & & & $<0.01$ & \multicolumn{2}{|c|}{$<0.05$} \\
\hline & & & & $<0.005$ & \multicolumn{2}{|c|}{$<0.005$} \\
\hline
\end{tabular}

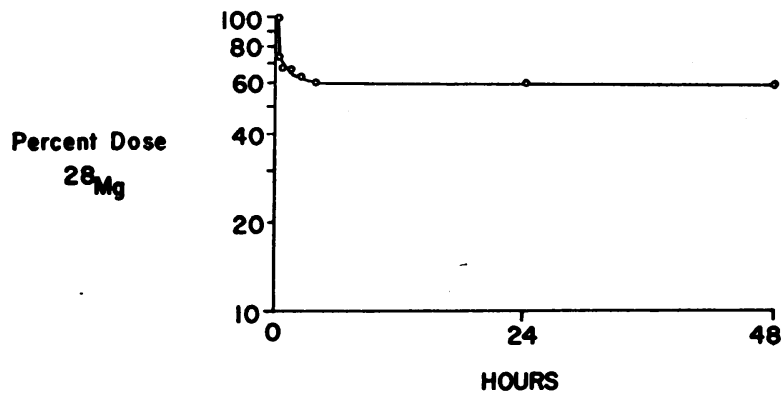

FIgURE 2 Example of ${ }^{28} \mathrm{Mg}$ exchange with bone magnesium. The disappearance of ${ }^{28} \mathrm{Mg}$ from the incubating media is shown over the first $48 \mathrm{~h}$.

magnesium was $33 \%$ of bone magnesium in the control bone as compared with $29 \%$ in uremic bone. There was an excellent correlation between elutable and exchangeable magnesium in all bones as shown in Fig. $3(r=$ $0.92)$. Using the student paired $t$ test elutable and exchangeable magnesium were found not to be significantly different $(P>0.1)$. Because of the above similarities elutable and exchangeable magnesium pools are assumed to be the same, and the terms will be used interchangeably throughout the remainder of the paper. Data presented in this paper was obtained with the bone elution technique.

The elutable magnesium pool was significantly higher in uremic bone (Table II).

Nonexchangeable magnesium pool. The major increase in bone magnesium in uremic bone is in the nonexchangeable fraction (Table II). To determine the effect of incineration on mobilization of this nonelutable pool graded heating was performed for $2 \mathrm{~h}$ at each temperature in a control bone, normal magnesium uremic bone, and high magnesium uremic bone. The elutable magnesium did not change in any bone from room temperature to $500^{\circ} \mathrm{C}$. At $550^{\circ} \mathrm{C}$ the nonelutable pool suddenly became

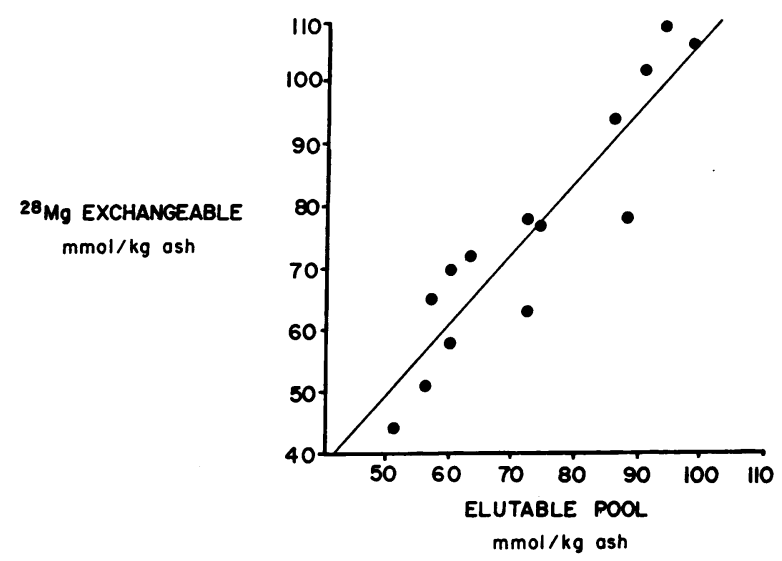

FIgURE 3 Correlation between exchangeable $\mathrm{Mg}$ and elutable $\mathrm{Mg}$. 
TABLE II

Bone Magnesium Pools

\begin{tabular}{|c|c|c|c|c|}
\hline & \multicolumn{2}{|c|}{ Cortical bone $\mathrm{Mg}$} & \multicolumn{2}{|c|}{ Trabecular bone $\mathrm{Mg}$} \\
\hline & Control. & Uremic & Control & Uremic \\
\hline & \multicolumn{2}{|c|}{$\mathrm{mmol} / \mathrm{kg}$ ash } & \multicolumn{2}{|c|}{$\mathrm{mmol} / \mathrm{kg}$ ash } \\
\hline Total $\mathrm{Mg}$ & 176 & 256 & 211 & 323 \\
\hline SD & 10 & 62 & 10 & 70 \\
\hline$P$ & \multicolumn{2}{|c|}{$<0.0025$} & \multicolumn{2}{|c|}{$<0.0005$} \\
\hline Elutable & 59 & 78 & 61 & 96 \\
\hline $\mathrm{SD}$ & 10 & 16 & 6 & 29 \\
\hline$P$ & \multicolumn{2}{|c|}{$<0.01$} & \multicolumn{2}{|c|}{$<0.0025$} \\
\hline Residual & 117 & 178 & 149 & 227 \\
\hline SD & 5 & 54 & 12 & 46 \\
\hline$P$ & \multicolumn{2}{|c|}{$<0.005$} & \multicolumn{2}{|c|}{$<0.0005$} \\
\hline \multicolumn{5}{|l|}{ Residual } \\
\hline $550^{\circ} \mathrm{C}$ & 16 & 99 & 55 & 190 \\
\hline \multirow[t]{2}{*}{ SD } & 9 & 83 & 47 & 112 \\
\hline & \multicolumn{2}{|c|}{$<0.005$} & \multicolumn{2}{|c|}{$<0: 005$} \\
\hline
\end{tabular}

elutable in the control bone and low magnesium uremic bone (Fig. 4). In the high magnesium uremic bone $25^{\circ} \mathrm{C}$ additional heating was required to mobilize this nonelutable pool. At the temperature $\left(550^{\circ} \mathrm{C}\right)$ that control and low magnesium uremic bone residual magnesium became elutable there was a sudden increase in crystal size as shown by sharpening the $\mathrm{X}$-ray diffraction peaks (Fig. 5). This change in $\mathrm{X}$-ray diffraction pattern occurred at a higher temperature in the high magnesium uremic bone (Fig. 5 ) but again coincided with mobilization of the residual magnesium pool. All control and uremic bones were studied unheated and at $550^{\circ} \mathrm{C}$. The elutable magnesium significantly increased in control bones (Table II) but not in the uremic bones. Eight additional studies were carried out with incineration at $500^{\circ} \mathrm{C}, 550^{\circ} \mathrm{C}$, and $600^{\circ} \mathrm{C}$. Again magnesium mobilization occurred simultaneously with crystal enlargement which was delayed by $50^{\circ} \mathrm{C}$ or more in uremic bone.

This effect of heat resistance in uremic bone appears to be related to the amount of magnesium present in the bone. Over $78 \%$ of bone magnesium was elutable following heating at $550^{\circ} \mathrm{C}$ in 9 out of 10 control bones and 6 out of 7 uremic bones with magnesium content less than $250 \mathrm{mmole} / \mathrm{kg}$ ash. In contrast no uremic bone with greater than $250 \mathrm{mmole} / \mathrm{kg}$ ash magnesium content had greater than $78 \%$ elutable magnesium following $550^{\circ} \mathrm{C}$ incineration (Fig. 6).

Effect of $\mathrm{Mg}$ equilibration and heating on surface magnesium

Unheated uremic and control bone was allowed to equilibrate in a barbital buffer containing $0,1,2$, and 4 $\mathrm{mEq} /$ liter $\mathrm{Mg}$. The mean values for change in bone magnesium in three control bones and three uremic bones are shown in Fig. 7. The slope of magnesium uptake and loss in the control and uremic bone was similar. However, the magnesium uptake in uremic bone was displaced to the right requiring higher magnesium levels
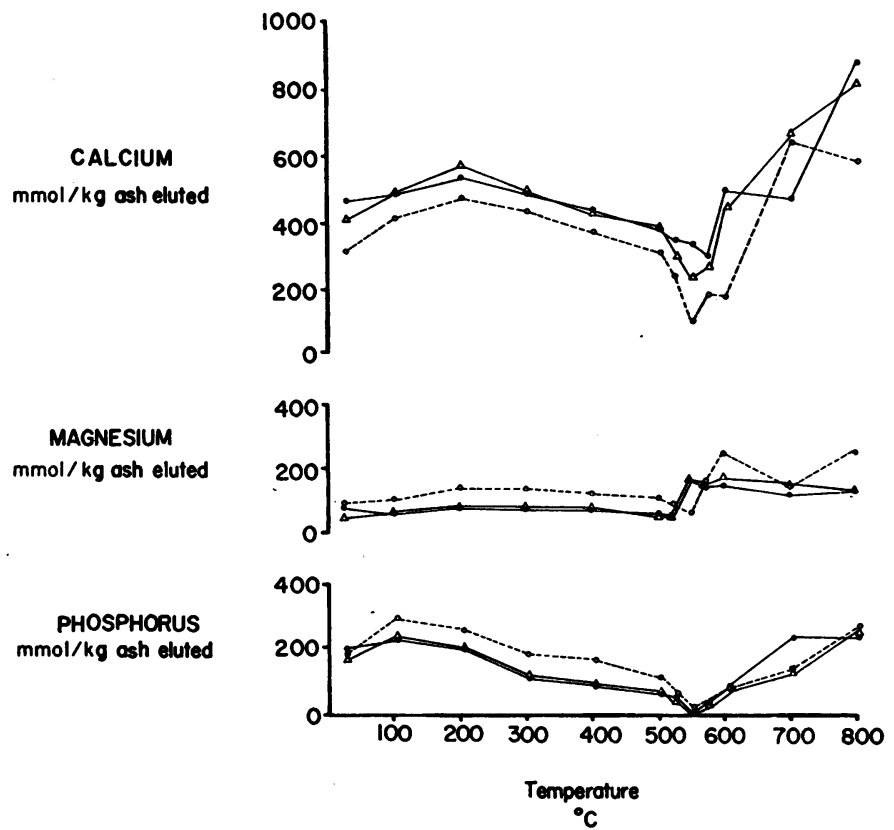

Figure 4 Effect of graded heating on elutable $\mathrm{Ca}, \mathrm{P}$, and $\mathrm{Mg}$ in three bones. Open triangles denote control bone, closed circles low $\mathrm{Mg}$ uremic bone and open circles high $\mathrm{Mg}$ uremic bone. 

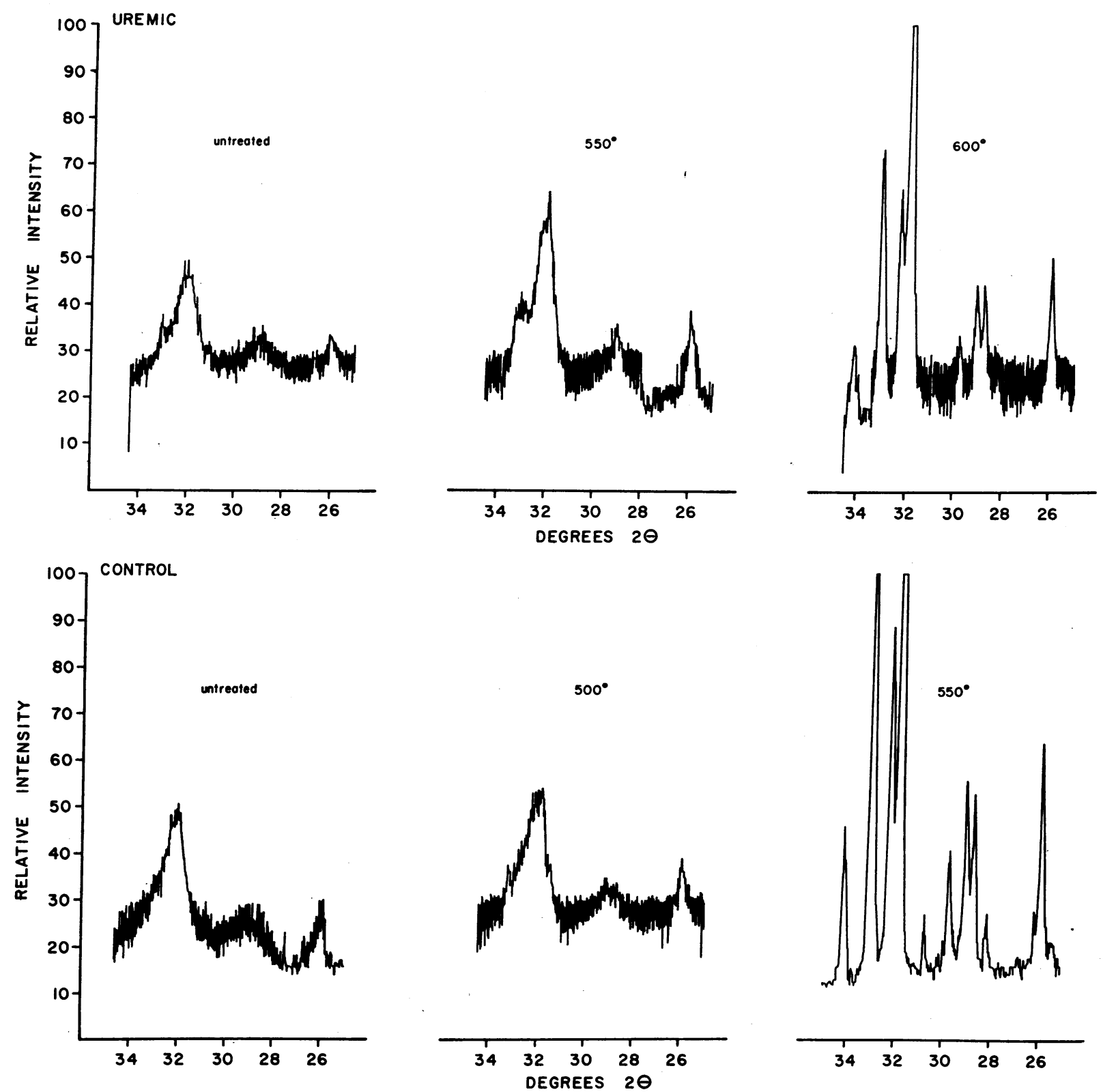

FIGURE $5 \mathrm{X}$-ray diffraction patterns of high $\mathrm{Mg}$ uremic bone and control bone following incineration.

to achieve a 0 change. The control bone crossed the 0 line at $1.5 \mathrm{meq} /$ liter, approximately normal serum magnesium levels, in contrast the uremic bone crossed the 0 line at approximately $2.6 \mathrm{meq} /$ liter $\mathrm{Mg}$ which would be similar to the serum magnesium concentration found in patients with chronic renal failure (7).

Surface $\mathrm{Mg}$ equilibration was not affected by incineration to $500^{\circ} \mathrm{C}$, a temperature that would result in total destruction of the organic matrix. Further heating of control bone to $550^{\circ} \mathrm{C}$ resulted in $\mathrm{X}$-ray diffraction evi- dence of enlargement of crystal size (Fig. 5) and almost total loss of surface equilibration (Fig. 8). In contrast crystal size was unaltered by $550^{\circ} \mathrm{C}$ in high $\mathrm{Mg}$ uremic bone and $\mathrm{Mg}$ equilibration was similar to that found in the unheated specimen (Fig. 8).

Effect of change in serum $M g$ on bone $M g$ pools. Bones from four patients with chronic uremia were studied after a mean period of 67 days following renal transplantation to determine how rapidly bone magnesium pools could be mobilized in vivo. In all patients elutable 


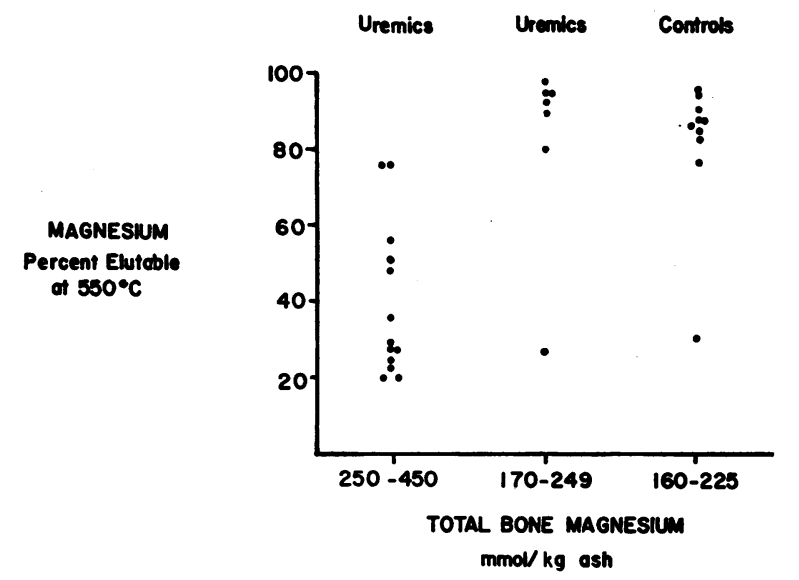

Figure 6 Percent elutable $\mathrm{Mg}$ following incineration at $550^{\circ} \mathrm{C}$ in control bone, low $\mathrm{Mg}$ uremic bone, and high $\mathrm{Mg}$ uremic bone.

magnesium had returned to normal values; whereas, residual magnesium was not significantly different from the uremic bone (Table III).

Bone from one patient with documented hypomagnesemia for $8 \mathrm{yr}$ was studied to determine the influence of long term magnesium depletion on bone magnesium pools. Total bone magnesium, elutable $\mathrm{Mg}$, and residual $\mathrm{Mg}$ were more than $2 \mathrm{SD}$ below normal in both cortical and trabecular bone (Table III).

\section{Cortical and trabecular bone magnesium}

Although there was no difference between cortical and trabecular bone calcium and phosphorus content, mag-

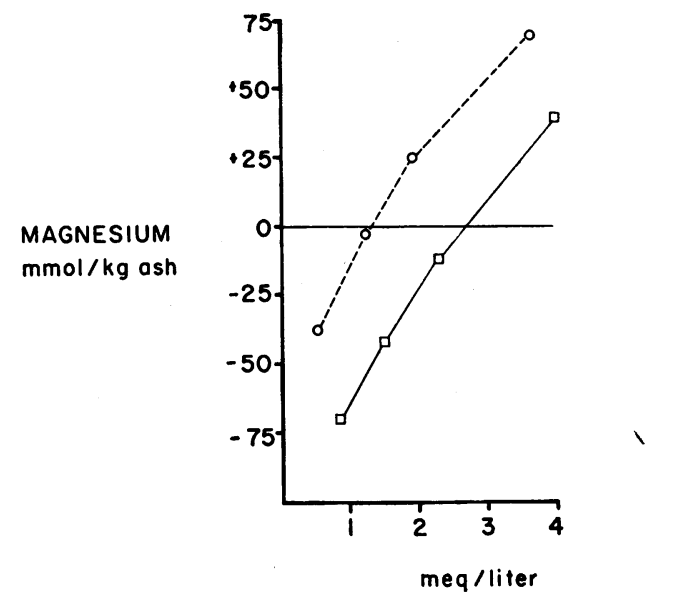

FIGURE 7 Equilibration study. Each line represents the mean values in three bones. Uremic bone is shown as the open squares and control bones as the open circles. Concentration of $\mathrm{Mg}$ in the equilibrating media at the end of the equilibration period is shown on the abscissa and change in bone $\mathrm{Mg}$ content on the ordinate.

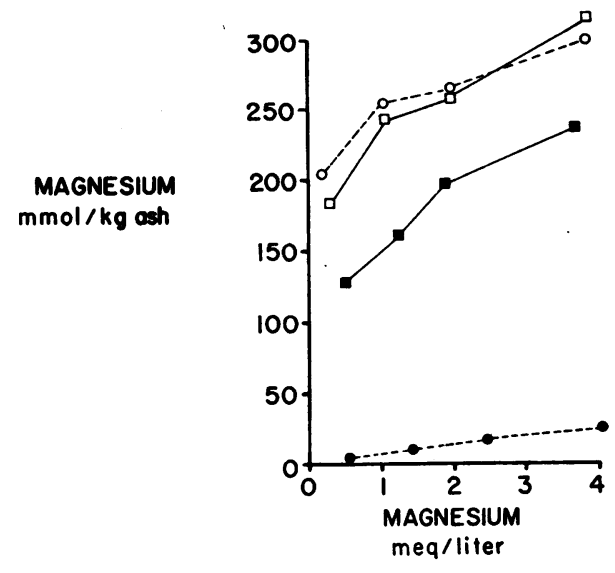

FIGURE 8 Effect of $550^{\circ} \mathrm{C}$ incineration on $\mathrm{Mg}$ equilibration. The solid line represents $\mathrm{Mg}$ equilibration before and the broken line after incineration at $550^{\circ} \mathrm{C}$. The open symbols are uremic bone and closed symbols are control bone. Concentration of $\mathrm{Mg}$ in the equilibrating media at the end of the equilibration period is shown on the abscissa and the change in bone $\mathrm{Mg}$ content on the ordinate.

nesium was consistently higher in trabecular bone. This difference persisted over a large range of bone magnesium levels (Fig. 9) $(r=0.88)$. Although elutable magnesium was slightly higher (Table II) the majority of increase in $\mathrm{Mg}$ in trabecular bone was in the nonelutable magnesium pool (Table II).

\section{DISCUSSION}

Bone contains at least two distinct magnesium pools. Normally $30 \%$ of bone magnesium is rapidly exchangeable, readily elutable, and equilibrates with an incubating media thus fulfilling the criteria of a surface limited pool

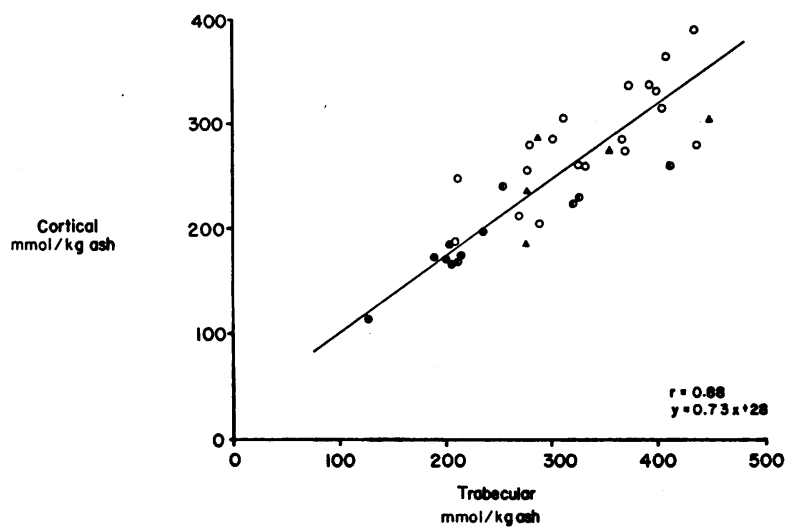

FIGURE 9 Correlation between total trabecular and cortical bone magnesium. The closed circles represent bone from patients with normal renal function, the open circles bone from dialyzed uremic patients, the triangles bones from post-transplant patients and the half closed circles bones from undialyzed uremic patients. 
TABLE III

Effect of Transplantation and Hypomagnesemia on Bone Magnesium Pools

\begin{tabular}{|c|c|c|c|c|c|c|c|}
\hline \multirow[b]{3}{*}{ Diagnosis } & \multirow{3}{*}{$\begin{array}{l}\text { Duration } \\
\text { renal } \\
\text { disease }\end{array}$} & \multirow{3}{*}{$\begin{array}{c}\text { Pre- } \\
\text { transplant } \\
\text { serum } \mathbf{M g}\end{array}$} & \multicolumn{3}{|c|}{ Post-transplant } & \multirow{2}{*}{\multicolumn{2}{|c|}{ Bone $\mathbf{M g}$}} \\
\hline & & & & Serum & & & \\
\hline & & & Ccr* & Mg* & Duration & Elutable & Total \\
\hline & $y r$ & meq/liter & $m l / \min$ & meq/liter & days & mmol & ash \\
\hline \multirow[t]{2}{*}{ PKD } & $4(d)$ & 2.9 & 60 & 1.5 & $74 \mathrm{C}$ & 67 & 238 \\
\hline & & & & & $\mathrm{T}$ & 68 & 288 \\
\hline \multirow[t]{2}{*}{ CGN } & $4(d)$ & 2.8 & 70 & 1.7 & $52 \mathrm{C}$ & 48 & 185 \\
\hline & & & & & $\mathrm{T}$ & 59 & 278 \\
\hline \multirow[t]{2}{*}{ MCD } & 16 & - & 46 & 1.8 & $68 \mathrm{C}$ & 64 & 236 \\
\hline & & & & & $\mathrm{T}$ & 62 & 237 \\
\hline \multirow[t]{2}{*}{$\mathrm{CGN}$} & 10 & 2.8 & 43 & 1.7 & $73 \mathrm{C}$ & 67 & 234 \\
\hline & & & & & $\mathrm{T}$ & 71 & 278 \\
\hline \multicolumn{8}{|l|}{ Magnesium losing } \\
\hline \multirow[t]{2}{*}{ Nephropathy } & 8 & 0.8 & 50 & 一 & $-\mathrm{C}$ & 37 & 115 \\
\hline & & & & & $\mathrm{T}$ & 32 & 133 \\
\hline
\end{tabular}

PKD, polycystic kidney disease; CGN, chronic glomerulonephritis; MCD, medullary cystic disease ; Ccr, creatinine clearance; (d), dialysis; $\mathrm{C}$, cortical; $\mathrm{T}$, trabecular.

* Mean values.

present either within the hydration shell or else on the crystal surface (10). The larger fraction of bone magnesium is nonelutable and nonexchangeable. Although it has been thought that magnesium is concentrated in osteoid $(2,12)$ this is not supported in the preserit study. Following incineration at $500^{\circ} \mathrm{C}$ a temperature that would completely destroy the organic matrix, neither size nor exchangeability of either magnesium pool changed. However, with further heating both $\mathrm{Mg}$ pools were affected. The surface pool no longer equilibrated with the incubating solution. This was associated with $\mathrm{X}$-ray diffraction evidence of enlargement of crystal size. Dallemagne and Fabry have shown that with incineration to $600^{\circ} \mathrm{C}$ crystal surface area decreases from $129 \mathrm{~m}^{2} / \mathrm{g}$ to $60 \mathrm{~m}^{2} / \mathrm{g}$ (13). It would be expected in turn that such a contraction of crystal surface area would markedly affect the surface limited magnesium pool. In addition the nonelutable magnesium pool was mobilized at $550^{\circ} \mathrm{C}$, the temperature at which crystal size suddenly increases. Heating results in diffusion of ions in a solid state with transformation of the crystal to its most stable form. Neuman and Mulryan using synthetic systems showed that upon aging magnesium is extruded from the mature apatite crystal (3). In addition Dallemagne and Fabry have suggested that upon heating bone the surface calcium enters defects in the apatite crystal displacing other electropositive elements (13). Although it is possible that heating releases magnesium from a magnesium containing apatite the present study does not exclude the possibility that the nonelutable magnesium pool is in the nonapatitic amorphous mineral phase of bone (14) which would also be transformed with heating.

The excess magnesium present in the bones of patients with chronic renal failure is distributed in both bone magnesium pools. The most apparent cause for the increase bone magnesium in uremia is the elevated serum magnesium levels associated with this state. Cunningham (6) and Clark and Belanger (5) showed that rats fed high magnesium intakes developed hypermagnesemia and increased bone magnesium. The correlation between bone and serum magnesium concentrations in five studies in rats and calves is shown in Fig. 10 (5, 6, 15-17). Data from the present study are also shown in this figure. It would appear that a similar correlation between serum and bone magnesium values exist in several species including man.

The finding that bone magnesium is usually increased in patients with chronic renal failure suggests that it may play a role in the abnormal calcium metabolism associated with this state. The increased surface limited magnesium would be expected to displace calcium in a mole for mole ratio (13). This may explain the reduced release of calcium found in uremic bone by Kaye, Frueh, and Silverman (18). Magnesium has been shown to stabilize certain amorphous calcium-phosphate deposits and to prevent crystal formation (19). In turn Russell and Avioli have shown that immature bone is increased in uremic rats (20), which could be a consequence of the increased magnesium content. The fact that high magnesium bones required greater heat to induce crystal enlargement further suggests that magnesium may stabilize and determine crystal size in uremic bone. The studies of Cunningham (6) and Clark and Belanger (5) further suggests that magnesium may prevent calcification of osteoid and interfere with bone metabolism. It thus seems possible that magnesium may play a role in 


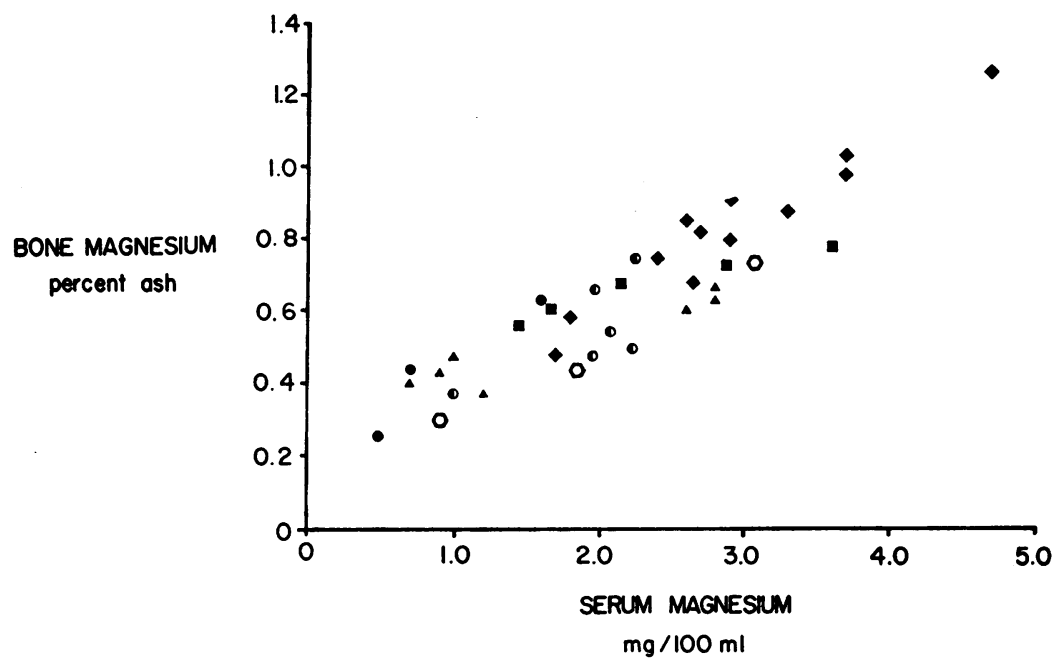

FIGURE 10 Correlation between bone and serum magnesium in five studies (references $5 \mathbf{\square}$, $6 \checkmark, 15 \bullet, 160$, and $17 \Delta)$. The hexagons represent the hypomagnesemic patient presented in this study and uremic and control values previously reported by the authors (7).

the pathogenesis of renal osteodystrophy. This has recently been suggested in regards to soft tissue calcification in uremia (21).

Hypermagnesemia and increased bone magnesium should be preventable in patients with chronic renal failure either by reducing magnesium intake or changing dialytic techniques. The in vitro studies would suggest that elutable magnesium should respond rapidly to changes in serum magnesium levels; whereas the nonelutable pool would equilibrate more slowly. This is supported in the post transplant studies. Elutable magnesium returned to normal levels in all patients within a mean period of 67 days following transplantation. However, the nonelutable magnesium pool was not different from the uremic bone. In contrast bone obtained from a patient with chronic hypomagnesemia had markedly reduced elutable, residual, and total bone magnesium levels. These findings suggest that the nonelutable magnesium pool is deposited at time of bone formation and mobilization is dependent on the resorptive progress. This would explain why bone magnesium falls more rapidly in growing animals than adult animals undergoing magnesium depletion since bone turnover is much more rapid in the former.

\section{ACKNOWLEDGMENTS}

The authors are grateful to Richard Trow for technical assistance and to Dottie Goodman for secretarial help.

This work was supported in part by Veterans Administration General Research funding.

\section{REFERENCES}

1. Walser, M. 1967. Magnesium metabolism. Ergeb. Physiol. 59: 185.

2. Blaxter, K. L. 1956. The magnesium content of bone in hypomagnesaemic disorders of livestock. In Bone Structure and Metabolism. C. E. W. Wolstenholme and C. M. O'Conner, editors. Little, Brown \& Company, Boston. 117.

3. Neuman, W. F., and B. J. Mulryan. 1971. Synthetic hydroxyapatite crystals. IV. Magnesium Incorporation. Calcif. Tissue Res. $7: 133$.

4. Breibart, S., J. Sup Lee, A. McCoord, and G. B. Forbes. 1960. Relation of age to radiomagnesium exchange in bone. Proc. Soc. Exp. Biol. Med. 105: 361.

5. Clark, I., and L. Belanger. 1967. The effects of alterations in dietary magnesium on calcium, phosphate and skeletal metabolism. Calcif. Tissue Res. 1: 204.

6. Cunningham, I. J. 1933. Magnesium in animal diets. The influence of the level of dietary magnesium on the magnesium and calcium contents of the bones, the bodies, and the blood serum of rats. N.Z. J. Sci. Technol. 15: 191 .

7. Contiguglia, S. R., A. C. Alfrey, N. Miller, and D. Butkus. 1972. Total-body magnesium excess in chronic renal failure. Lancet. 1: 1300.

8. Ben-Ari, J., G. M. Berlyne, J. Szwarcberg, J. Kaneti, G. M. Danovitch, and M. Kaye. 1972. Increase in bone magnesium content in uraemic man. Abstracts of the 5th International Congress of Nephrology. 168.

9. Pellegrino, E. D., R. M. Biltz, J. M. Letteri, N. D’Angelo, and S. H. Cohn. 1973. Chemical anatomy of uremic bone disease. Clin. Res. 21: 735.

10. Neuman, W. F., and M. W. Neuman. 1958. The Chemical Dynamics of Bone Mineral. University of Chicago Press, Chicago.

11. Chen, P. S., T. Y. Toribara, and H. Warner. 1956. Microdetermination of phosphorus. Anal. Chem. 28: 1756.

12. Duckworth, J., and W. Godden. 1943. The replenishment of depleted skeletal reserves of magnesium. Biochem. J. $37: 595$.

13. Dallemagne, M. J., and C. Fabry. 1956. Structure of bone salts. Ciba Foundation Symposium Bone Structure and Metabolism. Little, Brown \& Company, Boston. 14 . 
14. Posner, A. 1969. Crystal chemistry of bone mineral. Physiol. Rev. 49: 760.

15. Smith, R. H. 1959. Calcium and magnesium metabolism in calves. 4. Bone composition in magnesium deficiency and the control of plasma magnesium. Biochem. J. $71: 609$.

16. Forbes, R. M. 1964. Mineral utilization in the rat. II. Restoration of normal tissue levels of magnesium and calcium following magnesium deficiency. J. Nutr. 83: 44.

17. Martindale, L., and F. W. Heaton. 1964. Magnesium deficiency in the adult rat. Biochem. J. 92: 119.

18. Kaye, M., A. J. Frueh, and M. Silverman. 1970. A study of vertebral bone powder from patients with chronic renal failure. J. Clin. Invest. 49: 442.

19. Bachra, B., O. Trautz, and S. Simon. 1965. Precipitation of calcium carbonates and phosphates. 3. Effect of magnesium and fluoride ions on the spontaneous precipitation of calcium carbonates and phosphates. Arch. Oral Biol. $10: 731$.

20. Russell, J. E., and L. V. Avioli. 1972. Effect of experimental chronic renal insufficiency on bone mineral and collagen maturation. J. Clin. Invest. 51: 3072.

21. Contiguglia, S. R., A. C. Alfrey, N. Miller, D. E. Runnells, and R.. Z. LeGeros. 1973. Nature of sof tissue calcification in uremia. Kidney Int. 4: (No. 3, Sept.) In press. 